Boston University School of Law

Scholarly Commons at Boston University School of Law

Faculty Scholarship

2001

\title{
Quality Control, Enterprise Liability, and Disintermediation in Managed Care
}

Nicole Huberfeld

Boston University School of Public Health; Boston University School of Law

Follow this and additional works at: https://scholarship.law.bu.edu/faculty_scholarship

Part of the Health Law and Policy Commons

\section{Recommended Citation}

Nicole Huberfeld, Quality Control, Enterprise Liability, and Disintermediation in Managed Care, 29 Journal of Law, Medicine and Ethics 305 (2001).

Available at: https://scholarship.law.bu.edu/faculty_scholarship/896

This Article is brought to you for free and open access by Scholarly Commons at Boston University School of Law. It has been accepted for inclusion in Faculty Scholarship by an authorized administrator of Scholarly Commons at Boston University School of Law. For more information, please contact lawlessa@bu.edu. 


\section{Quality Control, Enterprise Liability, and Disintermediation in Managed Care}

\author{
John V. Jacobi and Nicole Huberfeld
}

$\mathrm{T}$ he Institute of Medicine (IOM) has returned the problem of medical error to the top of the health-care agenda. Its report that 44,000 to 98,000 patients die each year as a result of medical errors in American hospitals has renewed scholarly interest in health system quality control. ${ }^{1}$ In To Err Is Human, the IOM provides a vivid picture of a health-care system riven with serious quality problems. It calls for systems-based error-reduction methods borrowed from other high-risk industries and forcefully argues against the traditional tendency to assign accountability primarily to individual physicians. Most errors, the IOM argues, can be successfully addressed by engineering systemic fail-safe protections against the inevitable failings of human actors.

Medical malpractice litigation serves important compensatory and quality-improvement roles for victims of medical negligence. ${ }^{2}$ But the malpractice system's effectiveness is impaired by its narrow focus and its impulse to blame individual physicians for medical injuries. Can medical malpractice law be brought into harmony with system-focused error-reduction theory, as advocated by the IOM report? Legal theorists have long advocated a shift from individual physician liability to enterprise liability as a means of improving medical quality oversight - a shift now cautiously endorsed by the IOM. ${ }^{3}$ Enterprise liability seems to meld well with the prescription for a shift in accountability from individuals to systems by placing liability-driven incentives on organizations with both sufficient scope and organizational control to address system errors. The attention the IOM has drawn to the problem of medical error may renew policymakers' interest in enterprise liability.

In this article, we examine the potential of enterprise liability in light of current health-care finance realities. We

Journal of Law, Medicine \& Ethics, 29 (2001): 305-322.

(C) 2001 by the American Society of Law, Medicine \& Ethics. begin by addressing background issues of medical malpractice theory and the development of proposals for a form of plan-based enterprise medical liability centered on managed care organizations (MCOs). We then describe recent trends in the evolution of more loosely structured MCOs, including the emergence of "disintermediated," or patient-directed, plans. We examine the extent to which these developments weaken the rationales for plan-based enterprise liability. We conclude nevertheless that plan-based enterprise liability best serves the goal of reducing medical injury by permitting a focus on entities with sufficient scope to translate liability pressure into support for systemic risk-reduction measures. Advancing plan-based enterprise liability in an era of disengaged MCOs will require an extension of tort liability to firms with little control but much influence over their business partners.

\section{The Medical Malpractice System AND QUALTTY CONTROL}

The general strengths and weaknesses of the medical malpractice system are well developed in scholarly literature and will only be summarized here. In the current context, it must be observed that malpractice actions are not exclusively, or even primarily, about quality control; rather, they are intended to provide compensation for losses flowing from negligent medical injury. Three major justifications exist for the current medical malpractice system. First, our society has deemed it proper for an innocent victim to recover her losses from the person who negligently caused her injury. Second, society at large is served to the extent the malpractice system assures that a negligently injured person will not be rendered destitute, and socially unproductive, for want of funds to finance needed medical and rehabilitative care. Third, the malpractice system purports to deter 
negligent health-care providers from performing substandard care in the future.

The first and second justifications, compensation of the innocent victim and prevention of destitute citizens, are far from perfect in their execution. Malpractice litigation is an expensive process for all participants in terms of the financial costs of litigation, the time spent resolving claims, and the delays experienced in clearing claims. ${ }^{4}$ The malpractice system is, like the tort system generally, "an exceedingly costly insurance system." In addition, as the Harvard Study researchers concluded, the malpractice system is remarkably imprecise in identifying those injured persons most deserving of recovery for negligent medical injury. ${ }^{6}$ This imprecision is evidenced in at least two ways: The number of malpractice claims filed is dwarfed by the number of serious negligent injuries suffered, and the malpractice cases resulting in some recovery frequently do not involve evidence of an actual negligent cause of injury. The compensation aspect of the malpractice system seems, then, to suffer from underinclusion of negligently injured persons and from imprecise sorting between valid and invalid claims. ${ }^{7}$ This imprecision and expense in the malpractice system has led, in part, to the call for alternative compensation systems for victims of medical error, including various forms of enterprise liability. ${ }^{8}$

The third justification for the medical malpractice system is deterrence of negligent injury, or reduction in medical errors. The deterrence function is assumed to underpin negligence law in general, ${ }^{9}$ and malpractice law in particular. ${ }^{10}$ The rationale of the deterrent effect can be articulated as a four-part causal chain.

First, a patient suffers a medical injury under circumstances suggesting that the physician may have deviated from norms of professional conduct. The compensation potentially available to the injured patient provides the incentive for the patient to bring the claim forward.

Second, experts testify and jurors contemplate whether the injury was caused by an unexcused deviation from professional standards of care. In this trial process, the defendant-physician's conduct is compared to peer-derived norms.

Third, the jury assesses liability (or not), providing a public, societal judgment as to the point at which departure from peer standards merits sanction. In theory, then, a plaintiff's verdict and consequent money judgment deters the defendant-physician from departing from professional standards in the future. ${ }^{11}$

Fourth, the broader physician population is deterred through a simple feedback process. Physicians practice pursuant to their understanding of appropriate professional norms. They learn of malpractice judgments, which purport to hew to professional norms, and the accretion of these judgments creates a text from which physicians may infer the standard by which society will judge their conduct. The monetary awards to plaintiffs provide the incentive for physicians to obtain knowledge of judgments and to conform their conduct to the standards on which those judgments were based. ${ }^{12}$

In practice, however, well-understood limitations impede both the specific and the general deterrent effects. From a psychological perspective, the utility of liability judgments as a deterrent depends on an actor's having a high degree of certainty that the sanction will result from a deviation from professional norms. ${ }^{13}$ From an economic perspective, the success of liability judgments as a deterrent depends on a threat of financial loss that is convincing enough to motivate an actor to alter his behavior to avoid the injury. ${ }^{14}$

While even harsh critics agree that the malpractice system deters some disfavored conduct, ${ }^{15}$ the deterrent effect of any negligence regime is diminished (under either a psychological or economic analysis) to the extent the regime fails to directly link the sanction with the disfavored behavior. ${ }^{16}$ The disconnect between substandard conduct and incurring sanctions in the malpractice system is caused by at least four elements. First, substandard practice does not result in liability if the patient does not suffer an injury. ${ }^{17}$ Second, only a small percentage of patients suffering a negligent injury ever file a claim. ${ }^{18}$ The failure to file may be the result of the patient's lack of notice of the negligent injury ${ }^{19}$ or a prelitigation judgment by attorneys that the case is not economically rewarding after comparing possible recovery to potential contingent fees. ${ }^{20}$ Third, the common law negligence theory of setting enforceable standards through the accretion of fact-specific cases does not feasibly permit physicians to discern discrete rules that are useful to their practice of medicine. ${ }^{21}$ Fourth, the large majority of tort cases, including malpractice cases, are settled before trial, thus impeding the system's public rule-setting function..$^{22}$

Despite its pitfalls, the malpractice system does provide some marginal effect in deterring medical injury. ${ }^{23}$ Its inefficiency and narrow orientation toward physician fault limit its utility, however. Theorists, joined now by the IOM, have argued that one relatively simple means of achieving improvement would be to shift the focus of malpractice liability from the individual physician to the institution. This shift in focus is purported to hold the potential to improve the performance of the medical malpractice system and bring it into harmony with the systemic orientation of the errorreduction movement.

\section{ENTERPRISE LIABILITY}

\section{A. Development of enterprise liability theory}

Tort theorists have advocated a shift in focus in personal injury law for several decades. Particularly in the products liability area, assigning liability to a large enterprise (usually the manufacturer of the product) is argued to improve the tort system by reducing transaction costs and by improving 
the deterrent effect, thereby reducing the frequency and severity of accidents. ${ }^{24}$ The movement toward enterprise liability has been gradual, as new theories against enterprises supplement, but do not replace, existing causes of action against individuals on the same set of facts. In health-care law, the natural candidate for enterprise liability has been the hospital; here, too, the process has been evolutionary and cumulative, with old claims against physicians and new claims against hospitals existing side-by-side.

Tort law has evolved over recent decades to increase the theories under which hospitals can be found responsible for patient injuries. For example, hospitals have been found vicariously responsible for the negligence of their physicians through theories of ostensible agency and apparent authority, even when the physicians were independent contractors. ${ }^{25}$ Hospitals have also been found directly liable for patient injuries when they failed to credential and supervise physicians properly ${ }^{26}$ or when they failed to ensure that facilities and equipment necessary for patient care were reasonably available. ${ }^{27}$ The courts, albeit in a "piecemeal and erratic" fashion, have "channeled" medical liability toward the hospital enterprise. ${ }^{28}$

Enterprise liability theorists have moved farther away from traditional medical malpractice norms. The American Law Institute (ALI), in its 1991 report recommending enterprise liability for medical malpractice, recognized the developments in common law toward hospital liability. ${ }^{29}$ However, the report advocated "a much sharper break with the status quo," proposing to go beyond adding hospital liability to that of physician liability. The ALI recommended exclusive hospital liability in cases in which the physician negligently caused medical injury in a hospital, thereby exculpating the physician from legal liability. ${ }^{30}$ The ALI settled on the hospital as the focus of liability for at least two reasons. First, the common law has been moving in that direction; and second, the hospital is the entity responsible for organizing complex patient care and is the site at which most of the incidents giving rise to malpractice litigation have occurred. ${ }^{31}$

The stronger form of enterprise liability would designate the hospital as the sole defendant in most malpractice cases. ${ }^{32}$ Reducing the number of defendants to one could simplify the litigation process, speed the delivery of compensation to successful litigants, and increase the proportion of the recovery that goes to the malpractice victim. In short, enterprise liability is expected to reduce transactions costs. ${ }^{33}$ But enterprise liability also holds promise as a means to improve the medical malpractice system's deterrent effect, thereby potentially reducing medical injury.

\section{B. Deterrent effect}

The malpractice insurance system contains elements that inherently interfere with the corrective signals sent to physicians via malpractice litigation. As described above, only a very small percentage of victims of negligent medical error file malpractice claims, which could lead to underdeterrence. Nevertheless, a deterrence scheme can be effective, even if it significantly underdetects faulty conduct, if it includes both significant penalties and publication of punishments. This the malpractice litigation system arguably does, because the size of malpractice judgments, coupled with the significant non-financial costs to defendant-physicians, packs a significant wallop. ${ }^{34}$ The malpractice insurance system, however, shields physicians from the blow in a way that impairs the litigation system's deterrent effect.

We are not arguing that liability insurance does not provide an important protection for physicians, who face a great deal of uncertainty under the current liability system. For instance, injuries can result from a momentary slip that even the most careful physician cannot guard against; ${ }^{35}$ a lapse in skill or judgment can lead to a malpractice action only if it happens to cause an injury; ${ }^{36}$ many of those who are injured never sue $;{ }^{37}$ those who do file claims are frequently not victims of negligence; ${ }^{38}$ and the amount of each judgment is related not to the degree of fault or egregiousness of the medical error committed, but rather to the severity of the resulting injury and to entirely exogenous factors, such as the age, class, and social responsibilities of the injured patient. ${ }^{39}$ In the face of such uncertainty, liability insurance is an absolute necessity if physicians are to practice without the threat of imminent bankruptcy hanging over their heads.

But if physicians are insulated by insurance from the financial effects of liability judgments, insurance becomes the enemy of deterrence in the quality context. ${ }^{40}$ If insurance premiums were associated with past experience, insurance could shield the insured from unpredictable losses, while still maintaining substantial incentives to avoid injuries. ${ }^{41}$ But malpractice insurance underwriters rarely use past experience as an element of premium pricing. Instead, they tend to charge uniform premiums, varying them only on the basis of practice specialty and geographic location. ${ }^{42}$ In addition, the insurance is often "first dollar," with physicians bearing few co-payment or deductible responsibilities. ${ }^{43}$ Physicians are thus completely insulated from the financial effects of malpractice judgments, and the looked-for deterrent effect of malpractice actions is "diluted." 44 This feature of malpractice insurance does not arise from inattention or corruption; it is a function of the difficult or impossible task of making valid actuarial judgments about future physician malpractice incidence on the basis of past experience. ${ }^{45}$

These actuarial difficulties do not apply in writing malpractice insurance for hospitals. Hospitals are involved in a much larger volume of treatments than any individual physician, and they are therefore subjected to a proportionately larger number of malpractice claims. This regular and large volume of experience allows insurers to amass adequate data to tie hospitals' malpractice premiums to their 
actual history of claims, thus permitting hospitals to occupy the "middle ground" in which they enjoy some protection from uncontrollable losses, while their ability to control the incidence of claims is rewarded by moderation of malpractice premium rates. ${ }^{46} \mathrm{~A}$ sufficiently large hospital has enough volume and claims experience to form its own actuarial pool. Increasingly, such institutions take advantage of their scale by electing to self-insure, in which case the rewards for reducing claims is obvious and direct. ${ }^{47} \mathrm{~A}$ shift in focus "from the individual physician to the hospital ... could vastly increase injury-prevention incentives" otherwise frustrated by the malpractice insurance underwriting system. ${ }^{48}$

Enterprise liability thus has the potential to clarify the economic signals sent by malpractice judgments. In a physician-oriented system, the signals are muffled by ubiquitous, community-rated liability insurance. ${ }^{49}$ Hospitals incur a high volume of claims; and actuarially valid, experience-rated premiums, or self-insurance, are therefore feasible, permitting premiums or liability costs to vary with claims experience. This improvement might seem too abstract to garner much interest were it not for the closely related and more significant gain enterprise liability offers: The economic signals will be transmitted to entities that are more capable of using the data to achieve error reduction.

One potential effect of enterprise liability would be increased scrutiny of, and pressure on, "accident-prone" physicians. ${ }^{50}$ Physician-oriented malpractice insurance manages to screen out only the very worst physicians. Hospitals facing liability for injuries occurring within their walls would have every incentive to screen out physicians committing malpractice; further, they would have incentives to develop valid mechanisms, such as pęer review, to identify underperforming physicians before they commit medical errors. ${ }^{51}$ Thus, the basic but bedeviling task of weeding out (or limiting the practice of) physicians most likely to injure would be better performed by hospitals in an enterprise liability system.

The IOM, however, made a compelling case that reducing medical error is not so much about eliminating bad-apple physicians as minimizing the likelihood and effect of human error. ${ }^{52}$ In its report, the IOM focused on the experience of "other high-risk industries" in which error-reduction efforts long ago turned from blaming individual human actors to anticipating - and building safety systems around - inevitable human failings. ${ }^{53}$

Similarly, the ALI's 1991 study urged a focus on error reduction primarily through hospitals' organized and prospective quality-improvement efforts as each hospital gained the incentive to "use its organization levers" to improve care. ${ }^{54}$ The ALI study reasoned that enterprise liability would rely on the organizational and professional capabilities of hospital medical staffs, nursing staffs, and other skilled agents to improve safety:
[T] he inadvertent mishaps of the individual actor, even if they are not deliberate and are only minimally deterrable, are dangerous and need to be contained to the extent possible. The best vehicle for identifying and dealing with such incidents is the organization in which the doctor practices. The memory of the institution can serve to record and piece together patterns in a host of apparently idiosyncratic incidents. The collective wisdom of the hospital team can be pooled to devise feasible procedures for guarding against the ever-present risk of occasional human failure by even the best doctors....5

The ALI study also tied together the deterrence function and the issue of hospitals' institutional competence to effect error reduction: "Not only does the organization have a greater capacity to establish such quality assurance programs, but it is also more likely to be influenced to do so by the incentives created by tort liability." 56

Ultimately, advocates saw in hospitals the appropriate locus of the liability system's deterrence efforts and organized quality assurance activities. ${ }^{57}$ Hospitals directly organize and deliver health care on a daily basis, and they necessarily exercise close control over professional conduct, facilities, supplies, and bureaucratic procedures. ${ }^{58}$ In concert with accrediting bodies, they have for decades pursued formal programs of institutional quality improvement. ${ }^{59}$ In addition, some hospitals (usually major teaching institutions) pursue sophisticated research on quality assurance. ${ }^{60}$ Enterprise liability theorists agree with this systems approach, but some have shifted the spotlight from hospitals to health insurers.

\section{Shifting the enterprise liability focus to health plans}

The architects of the Clinton administration's ambitious health reform effort incorporated enterprise liability into their plan "as a demonstration project for improving the medical malpractice system." ${ }^{61}$ Like prior enterprise liability advocates, they hoped to reform the malpractice system in order to better serve quality-improvement goals. ${ }^{62}$ Although this effort moved enterprise liability to the national legislative agenda for the first time, it advanced enterprise liability with a twist: Instead of hospitals, health "plans," or MCOs, would be the responsible entity against which malpractice claims would be lodged. ${ }^{63}$ This effort drew on the prior arguments in favor of enterprise liability, recognizing the present "mismatch" between physician fault and victim compensation, the high transactions costs of the malpractice system, the failure of liability insurance to risk-rate physicians, and the consequent weakness of the system as a quality control measure. ${ }^{64}$ The inclusion of enterprise liability in the Clinton plan marked a 
shift toward health plans as the proposed responsible entity in malpractice litigation.

Evolution in the health-care delivery market precipitated this change in focus, as hospitals' control over care was seen to be waning, while that of plans was perceived to be on the rise. Hospitals have become somewhat less likely to be the site of malpractice as more and more complex procedures are performed in outpatient settings. Researchers from the National Center for Health Statistics performing the National Health Care Survey recently reported on this trend:

[M]any procedures that used to be performed only on an inpatient basis are increasingly being performed on an ambulatory basis.... In short, a very different mix of operations were performed during inpatient hospitalizations in 1998 than in 1985, with a considerable increase in cardiac procedures and less complex procedures shifting to ambulatory sites of care. ${ }^{65}$

In response to this trend, one state, previously requiring malpractice insurance only for physicians practicing in hospitals, amended its professional code to require malpractice coverage for physicians performing outpatient surgical procedures. ${ }^{66}$ Noting that hospitals were "losing patients to more cost-effective ambulatory and home-based services," ${ }^{67}$ and that hospitals may not have effective control over practitioners operating within their walls at any rate ${ }^{68}$ scholars shifted their focus to emerging and increasingly powerful managed care financing entities. ${ }^{69}$

MCOs promised the development of health-care management structures that seemed to recommend them as ideal candidates for enterprise liability - although it is important to separate the promise from its execution. Taking the evolution of MCOs in an optimistic light, we see organizations with a scale conducive to enterprise liability; they "can be large enough to pool risk and reap economies of scale, ... but small enough to allow effective coordination and management." ${ }^{\text {Tho }}$ Through their contractual relationships with physicians and facilities, MCOs have the structural ability to monitor and influence the provision of care. ${ }^{71} \mathrm{~W}$ ith this connective tissue in place, the addition of enterprise liability could be a catalyst to foster a cooperative quality-enhancing relationship. Physicians would be insulated from the litigation system, and their fortunes would be tied to some substantial degree (through contract) to the fate of the plan, which would now be the sole focus of the malpractice system. Under such circumstances, physicians may be more willing to regard quality as a collective goal and be willing to participate in systemic efforts to reduce errors. ${ }^{72} \mathrm{MCO}$ would have the benefit of broad perspective to design such errorreduction plans and to implement data systems and the "total quality management" tools that have been effective in other high-risk industries and that are finding applications in healthcare delivery. ${ }^{73}$

The advocacy of MCO-based enterprise liability has been tentative and conditional, pending evidence that MCOs could develop the quality-enhancing infrastructure needed for the task and that they would exercise their market power in the interest of quality improvement, rather than some other end. ${ }^{74}$ We turn next to examine the current state of MCOs' development of quality-improving methods of management, or what Clark Havighurst so aptly refers to as a "half-baked revolution." 75

\section{Decentralization and Disintermediation in Health Care}

Advocates of enterprise liability believed that a focus on hospitals would serve quality because hospitals had the levers to control a wide variety of activity critical to reducing medical errors, and they were properly incentivized to use them. As the marketplace evolved, scholars and politicians shifted their focus to MCOs. Enterprise liability was a sensible theoretical corrective to some of the faults of the malpractice system, and MCOs occupy a position in the health-care finance and delivery system such that they seem suitable candidates for the role of responsible enterprises; that is, they have substantial scale, broad connections with a variety of providers, and the informational and technical capacity to monitor the quality of complex systems. Recent history and apparent market trends suggest a turn in MCO development, however, that casts them in an unfavorable light as the ultimate guardians of medical quality.

\section{A. MCOs' unpredictable evolution}

Ardor for plan-based enterprise liability was always qualified by the observation that the plans suitable for a robust quality assurance role did not yet exist. The hope - and the explicit condition precedent to a firm endorsement of planbased enterprise liability - was that MCOs would develop the management systems and vision necessary to the task of overseeing quality improvement in the health-care delivery system. ${ }^{76}$ Well-integrated (and well-run) plans would be capable of creating and maintaining "[i]nstitutional quality improvement programs" because they could "view the quality of care they deliver in the aggregate, have the financial resources to develop medical information systems, and ... more easily implement programs for 'total quality management' (TQM) or 'continuous quality improvement' (CQI)." The thoughtful advocates of plan-based liability fully recognized the shortcomings of then-existing plans, but hoped for evolving improvements. ${ }^{78}$

The evolution of managed care has taken it in the wrong direction for enterprise-liability purposes. Health maintenance organizations (HMOs) have largely evolved away from 
tightly controlled staff and group models to more loosely organized network models. ${ }^{79}$ In response to consumers' concerns about lack of choice among providers, many plan sponsors have relaxed plan structures by offering preferred provider organization and point-of-service options in addition to HMOs. ${ }^{80}$ As networks have loosened, plans have not compensated for the loss in quality assurance capability with "virtual integration" through information technology; ${ }^{81}$ instead, they have focused almost single-mindedly on price competition. ${ }^{82}$

A recent report from the Office of Inspector General (OIG) at the U.S. Department of Health and Human Services confirms the failure of MCOs to take quality control duties seriously. ${ }^{83}$ The OIG investigated the extent to which MCOs report, as they are required to do by federal law, adverse actions against physicians to the National Practitioner Data Bank. The OIG studied a nine-year period during the 1990s and discovered that 84 percent of MCOs never reported an adverse event. ${ }^{84}$ The OIG acknowledged (with understandable skepticism) that no reportable event had occurred for those plans; but it also noted likely explanations, such as the plans' turning away from a clinical oversight role. ${ }^{85}$ It found that MCOs emphasize price, rather than quality; they rely on broad overlapping panels of independent physicians instead of staffs within the MCOs' control in response to consumer demand for choice; and they rely on "downstream entities," including hospitals and physician groups, to protect patients from dangerous physicians. ${ }^{86}$

The prospect for MCOs' taking aggressive quality control steps, within the current construct of enterprise liability, is probably dim. As consumers become increasingly distrustful of managed care plans, which they perceive as more interested in cost than quality, they are likely to resist the enhanced control over health-care delivery that MCOs would need to serve a quality management function. ${ }^{87}$ As Jacob Hacker and Theodore Marmor have recently described, it is difficult even to settle on the terminology relevant to a discussion in this regard. ${ }^{88}$

The ability of plans to exert control depends on several design choices that are not mutually exclusive, including the extent to which choice of provider is limited, the aggressiveness with which utilization control is performed, and the extent to which financial risk is shifted by the plans to intermediate entities or directly to physicians and other providers. ${ }^{89}$ But the task of implementing effective quality assurance structures is a large one, and plans have fallen far short of the expectations of those who saw them as engines of quality control.

In a recent article, Clark Havighurst captured the depth of the perceived failure of plans to organize themselves to improve quality:

Although today's health plans and their subcontractors have begun an important revolution, their actual accomplishments to date fall short of the goals envisioned for managed care when it first came on the scene in the 1970s and 1980s... [T] The vision of health plans actually organizing and directly overseeing providers has not been realized.... [T]oday's health plans act almost exclusively as general contractors at least once removed from providers and the actual delivery of care.... In reality, most plans are not rigorously selective in their choice of subcontractors.... [M] anaged care today means little more than subcontracting and capitation. ${ }^{90}$

If we accept this as true - that managed care has developed into an organized system of "subcontracting and capitation" - the question becomes whether devolution prevents managed care entities from responding to the need for quality controls. The answer may be that, despite the direction of managed care evolution described in the next section, responsibility may still be placed on the entity that is responsible for finance if rejection of a "control" model is accomplished.

\section{B. Emergence of the "anti-HMO"}

A recent development in health-care finance puts a fine point on the various observations that managed care is devolving. The trend toward "patient-directed care" illustrates how the tight reins of HMOs have caused a backlash toward decentralization. Because this development in health-care finance is both nascent and Internet-based, we cannot predict whether patient-directed care is a mere blip on the health-care screen or if it is microcosmic of a larger decentralization trend. Nevertheless, this development illustrates the need for altering enterprise liability theory to accommodate a less structured form of managed care.

The patient-directed care movement incorporates two still-developing elements, one concerning defined-contribution (as opposed to defined-benefit) health plans, and the other concerning increased consumer control, which can be described as a trend toward "disintermediated" plans. In the former, employers shift the means by which they determine the funding level of their contribution toward employee health benefits. In the latter, the role of the fiscal intermediary between employees and their health providers (e.g., an MCO or an administrative services organization retained by a selffunded employer) is reduced or eliminated.

The movement to a defined-contribution model of employer funding, while possibly troubling from an employee's perspective, would not necessarily mean a substantial change in plan design for enterprise liability purposes. Defined-contribution plans borrow from the now-familiar shift in retirement benefits to $401(\mathrm{k})$ plans, in which employees forego fixed-dollar pensions in favor of regular contributions to a 
retirement account, with the employee both directing the investment of the funds (usually within a range of options) and bearing the risk that the invested funds will grow more or less rapidly than expected. In the health coverage area, the concept is similar. Most employers now offer defined-benefit coverage, in which employees receive the promise of a set array of services, either at no cost to the employee or at a set employee cost. A shift to a defined-contribution plan would mean employees instead receive the promise of a set financial contribution toward the cost of health care, with the consequence of spending any balance - large, small, or uncertain - the responsibility of the employee. ${ }^{91}$ As the cost of health premiums once again rises ${ }^{92}$ employers see definedcontribution plans as a means of capping their health insurance costs, facilitating predictability, if not cost-containment. ${ }^{93}$

In practice, a shift to defined-contribution plans may result in little change from current practices. Many employees are already responsible for a substantial portion of their health-care premium, and many employers have been shifting more of the cost of health coverage to their employees, even under the so-called defined-benefit model. ${ }^{94}$ It may be, then, that employees will simply feel a slightly different form of incentive to choose a less expensive health plan. ${ }^{95}$ This mild modification in current practice would have little effect on the role of plans in the health-care delivery system, although it may lead to a reallocation of the cost of care between the employer and employee. ${ }^{96}$

In some defined-contribution models, employers would provide "vouchers" to employees and permit them total freedom in choosing an insurer in the individual market. ${ }^{97}$ Deep flaws in the individual insurance market would seem to counsel against this option; for example, premiums in the individual market are substantially higher than those in the group market. ${ }^{98}$ In addition, premiums for individual insurance in most states vary dramatically depending on factors such as age, family composition, and medical history. ${ }^{99}$ If vouchers are in equal face amounts for each employee, then they would be worth less for employees with higher risk profiles who use them in the non-group market. Complex schemes involving a version of risk adjustment for vouchers are proposed to compensate for this problem. ${ }^{100}$ The cost for such risk adjustment is not yet quantified in published sources. In combination, the added cost of individual (instead of group) coverage and of retrofitting the individual market to mimic group insurance for risk adjustment purposes will be daunting. ${ }^{101}$

The most intriguing aspect of patient-directed care could be characterized as the "anti-HMO"102 - the disintermediated health plan. Although many variations exist, some of which are more firmly established as concepts than as business plans, the heart of disintermediation is that it "enable[s] employers to bypass health plans altogether in managing their health benefits." ${ }^{103}$ One consulting firm touts the idea in the following terms:
Powered by the Internet, today's growing consumer market is driving toward a new way of providing, paying for and transacting health care. We are seeing the elimination of the middleman between the consumer and the caregiver (disintermediation) and the shift, by employers, from defined-benefit to defined-contribution health plans (devolution). ${ }^{104}$

While the Internet will permit interesting new means of gathering and transmitting information in the health-care industry, ${ }^{105}$ and many of the new businesses discussing disintermediated health plans have Internet features in their products, ${ }^{106}$ the innovative aspects of these health plans for purposes of this article do not depend on the Internet features.

Disintermediated plans are often described as a part of the managed care "backlash." 107 They permit employees free, or at least broad, choice of providers, and leave the contracting issues with respect to the provision of care to the employee and the provider; they generally favor direct patient control to any form of guidance or control by an employer or thirdparty intermediary. ${ }^{108}$ They have been called "do-it-yourself" networks, or "HMOs'R'Us.com." 109 Although they bear a resemblance to medical savings accounts, ${ }^{110}$ these plans are being offered in settings in which medical savings accounts may not be offered. For example, Medtronic, a $\$ 5$ billion publicly traded company, is offering its employees:

[T] he option to choose a personal care account plan through Definity Health.... [Medtronic] provides funds that go toward medical services.... Employees can only use the money for health care, and any money that is not spent rolls over into the next year. Under this plan, workers cannot keep the funds should they leave the company. Once the worker exhausts the money and the deductible, Medtronic pays the rest of the worker's medical bills. ${ }^{111}$

Many of the firms offering the cluster of services that comprise disintermediated plans offer similar product descriptions. Definity Health, Lumenos, and HealthMarket all describe a package in which employees would obtain an account from which they could fund health care of their choice from providers of their choice. The accounts are variously called "personal care accounts," "health savings accounts," and "HealthMarket savings accounts." 112 Any funds not expended in the year they are deposited by the employer "roll over" and remain in the employee's account, although they apparently may be used only for health purchases. ${ }^{113}$ The firms also offer various informational services - all, of course, available on the Internet - through which employees may obtain information about health-care providers and receive health educational materials. ${ }^{114}$ 
The buzzword for each of these firms is "choice." "[C]onsumers choose how to spend their health benefits dollars... Consumers select providers and care options, including alternative medicine." 115 "Consumers today have high expectations: They're decision-makers; they're self-reliant."116 "[Y]ou and your doctor can fulfill your health-care needs better than an insurance company." 117 These firms sell themselves as an opportunity for employees (if sponsored for membership by their employer) to evade control of MCOs altogether by exercising direct decision-making authority over the care they receive and the physicians who will provide that care. ${ }^{118}$

It is unclear how many subscribers such firms have enrolled at this point. It is clear that, while there is no stampede to move from insured models (including MCOs) to disintermediated plans, there is a genuine buzz about these models among employers and human resources managers. These plans seem to cater to the interest among employers to contain, or at least make predictable, their health budgets, and to "distance themselves from health care decisions" in order to avoid possible liability concerns. ${ }^{119}$ In addition, these plans have positioned themselves as bastions of choice and consumer control - in contrast to the reviled managed care plans. ${ }^{120}$

Will they "work"? The answer to that question depends on what we are using to measure success. One easy answer is that these plans present many of the detriments and possible benefits of medical savings accounts, the social accounting on which is still outstanding. ${ }^{121}$ But, while interesting, the issue is not whether defined-contribution plans in their current incarnation will last. They simply illustrate the need to redefine who is responsible for quality and why, regardless of the ever-changing managed care market. Few will debate the conclusion that managed care is continuing to evolve, or devolve, and has not found an apex (or a nadir). Today's managed care entities are far from the original HMO model that started in California. ${ }^{122}$ The reins have been loosened consistently over time. What was once a model of unified, centralized, preventative care has become a means for reimbursement through "subcontracting and capitation." Patient-directed care - whether in the form of defined-contribution plans, more extreme disintermediated models, or another incarnation altogether in the future - represents a spectrum of possible arrangements along which health-care finance has been moving and will likely continue to move. ${ }^{123}$

Accepting the idea of a spectrum and the inability (perhaps) of the health-care finance industry to settle on a model suggest a need to position the responsibility for quality assurance in a place that is not likely to continuously move along that spectrum. In the next section, we examine more particularly the effect that the evolution of the managed care industry has on the viability of plan-based enterprise liability and explain an altered formulation of the rationale for enterprise liability that accommodates the managed care evolution.

\section{Plan-Based Enterprise Liabiltty and Medical ErRors}

The time is ripe for a shift to enterprise medical liability. The evidence of high rates of medical error have focused the nation's attention on the need for systematic risk reduction. Enterprise liability meshes well with proposed programmatic steps to achieve safer care. The evolution of health-care delivery away from hospitals to outpatient settings highlights MCOs as entities with the suitable scope of operation to receive and distribute the incentives produced in an enterprise liability system. This section will describe the suitability of MCOs for this task, explore the effect of the decentralization of managed care, and argue that plan-based liability should nevertheless be pursued. While MCOs have largely lost their ability to control health-care providers' risky conduct, they have retained their ability to influence them to accept the systemic error-reduction measures sure to flow from the IOM's initiative.

\section{A. The fit}

The right need not be the enemy of the good in error reduction. The medical malpractice system seeks to provide compensation to victims of medical injury and to correct and deter health-care providers who cause such injury. Enterprise liability, whether as a modest evolution of the negligencebased tort system, ${ }^{124}$ or as a more dramatic shift to no-fault methods, ${ }^{125}$ hews to these goals. Enterprise liability attempts to improve the justice system by more efficiently serving the goals of compensation and deterrence. The IOM has invigorated the health system's error-reduction movement. This movement seeks to shift the perspective of error reduction from the instantaneous conduct of the provider when the error occurs to the longer-range context of the organization that permits - or does not engineer against - human error. Both enterprise liability tort theorists and the error-reduction movement target systems of a scale sufficient to effect changes in order to reduce the number and severity of accidents. Properly perceived, these movements can work hand in hand.

In the last few years, researchers have attempted to create a taxonomy of medical error in order to examine whether different remedies may be effective for different types of error. ${ }^{126}$ Some errors are "slips," unplanned deviations from intended conduct; some are "lapses," unplanned failures to carry out intended conduct; and some are "mistakes," failures in planning such that there is no deviation from intended conduct, but the planned conduct is "inadequate to achieve the intended objective." ${ }^{127}$ Errors can further be divided on the basis of the characteristics of the provider: "Some health care providers are incompetent, impaired or corrupt and make errors repeatedly despite multiple attempts at remediation. On the other hand, even the most highly trained and proficient professionals occasionally make mistakes." 128 
Would a shift to plan-based enterprise liability help to identify "incompetent, impaired or corrupt" physicians? Health plans would certainly have an incentive to screen out bad doctors if MCOs were held responsible for their errors. Plans would not, however, be in a position to pass direct clinical judgment on physicians' practices. As Abraham and Weiler have pointed out, plans are "one step removed from the actual delivery of care," and their information and influence would therefore be indirect. ${ }^{129}$ As we described above, this attenuation has only increased in recent years, and plans are likely to serve even less well in the future as direct or reliable conduits of clinical information. Plans could use data systems to correct for this deficit; for instance, they could monitor error rate by accumulating data of malpractice claims. History shows this to be no innovation, however, because malpractice carriers have had this capability and, while they can obviously identify the extreme outliers, they have found that the collectible data lacks sufficient statistical and actuarial power to predict future claims experience for most physicians. ${ }^{130}$

The emphasis of the IOM, however, is on the lapses and mistakes by qualified, conscientious providers. It has concluded that addressing the source of systemic errors - the conditions in the health-care delivery system that make human error and medical injury more likely to occur - is the key to quality improvement. ${ }^{131}$ Even the "slip" or "lapse" of an individual physician is capable of being placed in the "systems" context for error-reduction purposes. James Reason describes this perspective in the following terms:

The basic premise in the system approach is that humans are fallible and errors are to be expected, even in the best organizations. Errors are seen as consequences rather than causes, having their origins not so much in the perversity of human nature as in "upstream" systemic factors.... Countermeasures are based on the assumption that though we cannot change the human condition, we can change the conditions under which humans work. A central idea is that of system defenses. All hazardous technologies possess barriers and safeguards. When an adverse event occurs, the important issue is not who blundered, but how and why the defenses failed. ${ }^{132}$

An example of preventable error - drug errors (e.g., the administration of the wrong drug or of the right drug in the wrong dosage) - often involves a "slip" by a physician (e.g., she writes the prescription incorrectly). ${ }^{133}$ For an injury to occur, at least one other "slip" or "lapse" might occur (e.g., the pharmacist fails to catch the error). If the process of prescribing medications is regarded as a systemic issue, however, the analysis can treat a drug error as a "mistake" - that is, as an indication of a systemic failure to plan; here, a failure to plan for human error. A focus on the individual would blame the physician for her error and provide incentives (through, perhaps, individual malpractice liability) for her to avoid such errors in the future. A systems approach would assume the possibility of human error and engineer fail-safe mechanisms to catch them before they occur - for example, by employing computerized drug order entry systems with software capable of screening for a high percentage of drug errors caused by human "slips."134

Enterprise liability is, from this perspective, a superior approach for assessing liability for medical errors. Unlike the traditional malpractice approach, which ordinarily begins and ends its analysis with the actions of an individual physician, enterprise liability contemplates an enterprise of a scope sufficient to permit meaningful systems analysis. Theoretically, over a course of time, the enterprise can use its experience in many medical injury cases, or its internal analyses undertaken in anticipation of potential medical injury cases, to adjust the systems of care to prevent future injuries by controlling for providers' lapses and mistakes. The enterprise could use its control over the health-care delivery workplace and the data it aggregates by virtue of its participation in a large number of medical cases to correct the "conditions that cause errors." 135

To the extent the malpractice system moves toward enterprise liability, it would be incorrect to say, as have Studdert and Brennan recently, that the error-reduction movement is on a "collision course with the medical malpractice system." " 136 The IOM advocated a shift in focus from "blaming individuals." ${ }^{137}$ But it recognized that simply identifying quality-improvement methods and publishing them to caring professionals will not significantly advance the goals of error reduction. Rather, the "external environment" must create "pressures" or incentives for the health-care delivery system to implement error-reduction methods. ${ }^{138}$ The IOM declined to undertake an assessment of malpractice reform proposals, but it recognized that a shift to enterprise liability would be conducive to achieving its goals of error reduction. ${ }^{139}$ To the extent the tort system moves toward enterprise liability, the mechanisms of the tort system will align with those of the error-reduction movement.

Plan-based enterprise liability appears to be a happy marriage of finance and quality assurance structures. MCOs have consequential control over providers and data-gathering capabilities pursuant to their mission to organize networks and control cost. They could use the "levers" employed for cost containment to drive error reduction. In theory, MCOs could use their "carefully negotiated contracts" with providers as "the basis for coordination of quality improvement and accountability for error." ${ }^{140}$ MCOs could view care "in the aggregate" and employ their financial resources to implement "organizational improvements." ${ }^{141}$ The theory of enterprise liability seems tailor-made for the systemic errorreduction movement of which the IOM report is a part. 


\section{B. The tension}

The "fit" between the error-reduction movement and the theory of plan-based enterprise liability is sufficiently appealing that it is appropriate to question the extent to which the decentralization of MCOs frustrates a shift in the structure of the medical malpractice system. The evolution of managed care structures described above seems to undercut arguments in favor of plan-based enterprise liability from both the legal and health administration perspectives.

Tort theorists' embrace of enterprise liability is premised on its superiority in both providing compensation to victims and creating incentives for error reduction. The former is beyond the scope of this discussion. The error-reduction justification for enterprise liability springs from a conceptualization of the tort system as a regulatory device by which an enterprise (e.g., a manufacturer of a product) is held responsible for injuries its commercial activity causes. This assignment of responsibility is intended to impose riskreduction incentives on the organization producing the risky activity or product. This imposition is justified by the fact that the enterprise benefits from the ability to impose risk on society and, thus, it might fairly be asked to shoulder the burden when injuries result. The imposition is seen as sensible because the designated organization has primary control over the creation of the risk and the concomitant ability to exercise that control to reduce the scope of the risk. ${ }^{142}$

The ability of the responsible enterprise to exercise control over the conduct of others in order to reduce risk has been an important underpinning of enterprise liability. This control element is a common thread in the tort system's extension of liability beyond active tortfeasors to achieve safety ends. For example, liability has long been extended to otherwise blameless employers and principals when their employees or agents negligently cause harm, in large part because the employer or principal is believed capable of exercising control over risk-causing conduct. ${ }^{143}$ The ability of health-care enterprises to control individuals' behavior, and thereby reduce risk, similarly undergirds arguments for enterprise liability in medical malpractice. ${ }^{144}$ The incentive argument is simple: Regulators (here, the tort system) interested in error reduction should focus on enterprises empowered to control the conduct that creates risk. Application of pressure on the enterprise will induce it to exercise its control for the purpose of risk reduction. The diminution of that ability to control weakens one major support for any movement in the direction of enterprise liability.

From the health administration perspective, the decentralization of managed care diminishes the impulse to look to plans to drive error reduction. The IOM embraced the need for incentives to create safety: "The combined goal of the recommendations is for the external environment to create sufficient pressure to make errors costly to health care organizations and providers, so they are compelled to take action to improve safety." 145 Applying incentives to MCOs is a sensible step in this direction to the extent MCOs are capable of achieving risk reduction. However, a degree of organizational coherence has been seen as crucial to systems-based risk-reduction strategies. A recent study of hospital performance in risk reduction identified successful safety outcomes with a culture of shared goals, substantial administrative support for safety measures, strong leadership, and good information systems. ${ }^{146} \mathrm{~A}$ trend away from centralized control calls into question whether MCOs have these characteristics.

The greater the distance between MCOs and the delivery of care, the more salient the cautions are against plan-based enterprise liability. The attenuation of the relationship between MCO management and active care-givers raises concerns that pressure applied to MCOs will fail to translate to effective error reduction and may miscarry in the direction of inefficient or counterproductive consequences. ${ }^{147}$ MCOs that are not intimately engaged in the delivery of care may react to error-reduction pressure simplistically - for example, by "hanging out to dry" providers found to have caused an injury, regardless of the consequence to the goals of long-term safety. ${ }^{148}$

The argument for a marriage between plan-based enterprise liability and systematic medical error reduction is strongest when MCOs are tightly integrated health-care delivery and finance organizations. Under such circumstances, liability pressure serves both the historic tort interest in deterrence and the health administration goal of systems-focused error reduction. As MCOs tend toward disengagement from the control of health-care delivery, reexamination of the fit is necessary.

\section{Striking the balance}

The explosion of work on systems-based error reduction in an era of managed care presents an opportunity for coordination between the medical and legal systems that ought to be pursued. Were the revolution in managed care not, as Clark Havighurst correctly points out, "half-baked,"149 MCOs would be capable of providing a degree of control over the broad sweep of health-care delivery in a way that would clearly match the goals of both the tort and health administration systems.

We believe that plan-based enterprise liability remains a plausible method of harmonizing the need for accountability with the interest in avoiding the impulse to blame individuals. The scope of medical injury is large, and systems-based responses are called for. Health care - even high-risk, intrusive health care - is increasingly provided in outpatient settings, and hospitals are therefore an increasingly underinclusive choice as a responsible enterprise for malpractice purposes. Plans are at an organizational apex in the health-care delivery and finance system, and are therefore structurally able to relate - as employer, principal, or con- 
tracting partner - with all levels of the delivery system. Even in their diffuse state, MCOs are in the best position to focus liability pressure on error reduction. We focus on the indirect authority that MCOs possess, which provides the ability to influence rather than control; influence is a sufficient basis under these circumstances to extend enterprise liability to health plans.

MCOs control the payment for services by means of various types of contract. Their ability to influence their contracting partners as a condition of receiving payment is while more indirect than the power to direct, hire, and fire - powerful. That influence is currently exercised to the end of cost containment, and no structural reason exists to prevent this influence from being employed to the end of error reduction. We acknowledge that MCOs do not possess the degree of control over direct providers of care that has historically been associated with the extension of indirect tort liability. Employers can fire employees; principals can discharge agents. Both have historically wielded substantial authority to dictate their subordinates' conduct. Nevertheless, MCOs have, in place of this power of control, the power to influence.

The roots of enterprise liability in the tort system are consistent with such nakedly instrumental justifications for the assignment of liability. The goal of products liability law is to employ liability (in part) to create incentives that push manufacturers toward safety in their own activities as well as in their dealings with subcontractors. Manufacturers have no defense if a defect is traceable to poor work by a subcontractor, even if a manufacturer acted reasonably in accepting the subcontractor's component part. ${ }^{150}$ Liability can thus be extended to the conduct of those beyond the "control" of the responsible enterprise.

In some limited areas, tort law has advanced this regulatory interest to hold an actor responsible for the conduct of a party over whom the actor has some ability to influence, but not to control. Psychologists, for example, are sometimes held responsible for the conduct of their patients when the psychologists knew of the likelihood of injury but did nothing to prevent it or warn of its occurrence. ${ }^{151}$ Lenders are sometimes held responsible for the torts of their debtors, particularly to the extent they become involved in their debtors' business operations. ${ }^{152}$ In some situations, the tort system imposes liability for the actions of persons clearly beyond a defendant's control under the theory that the duty to prevent injuries is "nondelegable." 153

Without intending to minimize the political barriers to an extension of enterprise liability to MCOs, we believe that such an extension would be a modest - or at least not an unprecedented - extension of tort principle. Further, this purely instrumental justification squares with the rationalizations historically offered for enterprise medical liability, which has always been championed in part on the basis of its ability to extend incentives to a responsible entity to reduce risks caused by persons who otherwise would not be the enterprise's responsibility under tort law. The heart of the matter, however, must be a practical justification of planbased enterprise liability. If the imposition of enterprise liability on plans is unlikely to lead to a reduction in medical injuries, or if the collateral effects of such an imposition are unacceptable, plan-based enterprise liability ought not be pursued.

Plan-based enterprise liability "works" when it influences plans to induce providers to undertake sensible measures to avoid medical injuries. The incentives need not be perfect, only worth the cost. If the analysis of the IOM is approximately correct, the level of serious medical injury in the American health-care delivery system is sufficiently large to justify a considerable cost. The incentives created by a plan-based enterprise liability system must be evaluated in terms of their success in inducing direct providers of care to undertake appropriate safety measures. The nature of those safety measures, as the IOM has been at pains to point out, is not now well understood and arguably is not yet the subject of sufficient inquiry. The IOM has advocated for the creation of a national Center for Patient Safety to gather information and oversee and perform research necessary to achieve a " $50 \%$ reduction in errors over five years." ${ }^{154}$ Steps have been taken to create such a center within the federal government. ${ }^{155}$ Steps for systemic error reduction have been proposed in areas such as drug administration and anesthesiology. ${ }^{156}$ Further steps are likely to be process-oriented performance standards directed at safety outcomes.

The IOM has advocated that regulators, accreditors, and purchasers require or provide incentives to providers to adopt the forthcoming safety measures. These steps would be entirely appropriate. However, screening by regulators and accreditors has not proven in the past to do more than establish a very basic baseline; and in some instances (e.g., nursing homes), it has failed to accomplish the enforcement of even fundamental health and safety standards. Purchasers have a mixed record of attention to quality measures. While some purchaser groups are extremely engaged in quality measurement and improvement measures, the market in which health-care services are bought and sold remains startlingly insensitive to quality issues. ${ }^{157}$ Under such circumstances, the medical liability system certainly retains at least an interstitial role in quality assurance. The IOM recognized as much, and agreed that the most comfortable fit between its vision of systems-oriented quality assurance and the tort system is enterprise liability. How such a liability system will incentivize MCOs is clear; how they will translate that incentive to affect the conduct of health-care providers is not.

For reasons discussed above, MCOs are unlikely to attempt to affect health-care practices through direct management tools - that is, through directing health-care providers in the course of their patient care duties. Nor should they; they are simply too remote from the bedside to have 
meaningful influence in day-to-day operations. But the measures anticipated by the error-reduction movement are not minor tinkerings on a physician-by-physician basis, but basic process measures. One task recommended by the IOM is the creation of "feasible prototype systems (best practices) and tools for safety in key processes," for application in a variety of settings, such as:

- medication systems (from prescribing to administering);

- operating rooms and surgery processes;

- emergency departments;

- management of diagnostic tests, screening, and information;

- intensive care units;

- neonatal intensive care units;

- care of frail elderly (e.g., falls, decubitus);

- the use of simulation and simulators in health care; and

- team training and crew resource management applications in health care. ${ }^{158}$

Some process measures, such as the use of computer systems to check for prescription and administration errors, can properly be the subject of bargaining between contracting partners. If the government's patient safety center follows through on the creation of these prototype systems for reducing patient injury, MCOs could require that all contracting providers adopt the methods relevant to their practice.

MCOs would be incentivized to take this step for several reasons in a plan-based enterprise liability system. First, and most obviously, the requirement that its subcontractors adopt risk-reduction protocols will, if the protocols are valid, lessen the chances of a medical injury. Second, depending on the shape of the enterprise liability system, such a step may be taken into account in determining the quantum of damages for which the $\mathrm{MCO}$ would be responsible. ${ }^{159}$ Third, the enforcement of such a policy would be evidence of quality within the health plan's network, a feature that should be of some competitive value. Thus, the incentives appear to translate from the liability system, through a given health plan, to the plan's constituent parts, notwithstanding the plan's lack of instrumental control over health-care delivery operations.

Several implementation concerns should be noted, though they cannot be resolved here. First, one of the justifications for MCOs as the responsible entities is that MCOs have contractual relationships with health-care providers in large, small, and nonexistent institutional settings. This virtue becomes problematic when MCOs attempt to require compliance with complex error-avoidance protocols, as solopracticing physicians are unlikely to have the resources to comply that a large group practice would have. The protocols could be produced, however, by either the federal patient safety center or the health plans in a variety of forms suitable for providers of different scales of practice. The Fraud and Abuse Compliance Guidance, produced by the U.S. Depart- ment of Health and Human Services, is produced in such a variety of forms. ${ }^{160}$ The production of programmatic guidance suitably scaled to different types of organizations would blunt concerns that either larger or smaller providers would suffer competitive consequences unrelated to safety concerns.

Second, many people are covered by government insurance or by self-insuring employers. The application of plan-based enterprise liability fits uncomfortably in both situations. Government has moved, however, to "privatizing" public insurance, and most Medicaid recipients and many Medicare recipients are now members of private plans. Government would have to make a judgment with respect to its residual fee-for-service participants; it could either waive its governmental immunity to suit or simply exclude those beneficiaries from the liability system. The arguments for and against liability for self-insured employers are now the subject of discussion in the context of "patients' rights" legislation and will not be rehearsed here.

Third, many MCOs now include, due in large part to consumer demand, a provision permitting out-of-network benefits. These provisions permit insureds to receive partial coverage for care from a provider with no contractual relationship with the plan. This problem is significant. On the one hand, the solution could be to permit an exception to enterprise liability when an insured selects an out-of-network provider. The collateral consequence of such a solution may well be to limit a very popular manifestation of patient choice. On the other hand, we could hold plans liable under such circumstances; the fairness of such an imposition of liability, however, would stretch the theory to its breaking point.

\section{CONCLUSION}

The IOM report has generated momentum toward a systemic approach to medical error reduction. Two prominent health systems researchers recently noted that "[p]olicymakers are capable of taking action to protect human life in many other areas, but efforts directed at the health care system remain uncommon"; they argued that sustained attention is needed to make progress. ${ }^{161}$ Beyond attention, action is obviously necessary if medical injuries are to be reduced. Notably, the IOM, in a follow-up to its 1999 study, quoted Goethe: "Willing is not enough; we must do." 162 The IOM and other respected sources agree that a campaign of blaming individual physicians is not a prescription for improvement. Accountability is necessary, but to be effective, reforms must encourage systems and organizations to engineer around inevitable human failings.

That emphasis meshes well with proposed shifts in medical malpractice theory from a physician focus to an enterprise focus, a theory most recently fastening on MCOs as the appropriate responsible enterprise. It seems a happy coincidence. Pushes for change in the malpractice system usually seem 
more tied to the vagaries of malpractice insurance premium fluctuations than to patient safety. Now, however, the momentum toward error reduction might move policymakers to consider seriously the merits of plan-based enterprise liability. Enterprise liability places the incentives for improvement with organizations of a scale sufficient to influence providers' adoption of systems-based error-reduction methods. Health plans, unlike hospitals, have influence over the entire range of entities and providers involved in healthcare delivery and, therefore, have the potential to encourage system-wide safety measures.

Unfortunately, the renewed interest in enterprise liability comes at a time when plans are decentralizing and disengaging from direct control over patient care. The move to enterprise liability and, specifically, plan-based enterprise liability should nevertheless be pursued. Health plans continue to be business partners with the health-care providers who must be encouraged to adopt the error-reduction recommendations sure to emerge from any federal patient safety center. The financial influence health plans wield justifies the imposition of enterprise liability; their ability to condition continued business dealings on providers' adoption of error-reduction methods makes plan-based enterprise liability an essential adjunct to the error-reduction movement.

\section{REFERENCES}

1. L.T. Kohin, J.M. Corrigan, and M.S. Donaldson, eds., Committee on Quality of Health Care in America, Institute of Medicine, To Err Is Human: Building a Safer Health System (Washington, D.C.: National Academy Press, 1999), available at <http://books.nap.edu/books/0309068371/html/R1.html\# pagetop $>$ [hereafter cited as IOM Report].

2. Harvard Medical Practice Study Group, Patients, Doctors, and Lauyers: Medical Injury, Malpractice Litigation, and Patient Compensation in New York (Cambridge, Massachusetts: Harvard University, 1990); P. Weiler, Medical Malpractice on Trial (Cambridge, Massachusetts: Harvard University Press, 1991).

3. IOM Report, supra note 1, at 95-96.

4. P. Danzon, Medical Malpractice: Theory, Evidence and Public Policy (Cambridge, Massachusetts: Harvard University Press, 1985): at 187-95; P. Weiler et al., A Measure of Malpractice: Medical Injury, Malpractice Litigation, and Patient Compensation (Cambridge, Massachusetts: Harvard University Press, 1993): at $141-42$.

5. W. Landes and R. Posner, The Economic Structure of Tort Law (Cambridge, Massachusetts: Harvard University Press, 1987): at 9-14.

6. The Harvard Medical Practice Study, published in 1990, examined the rate of negligent and non-negligent medical injury and the relationship between the tort system and medical injury in the context of New York hospitals. See Weiler et al., supra note 4, at viii. See generally Harvard Medical Practice Study Group, supra note 2; T. Brennan et al., "Incidence of Adverse Events and Negligence in Hospitalized Patients: Results of the Harvard Medical Practice Study I," N. Engl. J. Med., 324 (1991): 370-76; L. Leape et al., "The Nature of Adverse Events in Hospitalized Patients: Results of the Harvard Medical Practice Study II," N. Engl. J. Med., 324 (1991): 377-84. The researchers found that use of the medical malpractice system correlated very poorly with receipt of a negligent medical injury. Most negligently injured patients never filed claims for compensation, and only about half of the patients who did file suffered a negligent injury. See Weiler et al., supra note 4, at 69-72.

7. Weiler et al, supra note 4, at 139-40.

8. See Weiler, supra note 2, at 134-39; D. Studdert and T. Brennan, "No-Fault Compensation for Medical Injuries: Making It Happen," JAMA, 286 (2001): 217-26.

9. See Landes and Posner, supra note 5, at 57-58; S. Shavell, Economic Analysis of Accident Law (Cambridge, Massachusetts: Harvard University Press, 1987): at 8; W.P. Keeton et al., Prosser and Keeton on Torts, 5th ed. (St. Paul, Minnesota: West Publishing, 1984): at 25-26; G. Schwartz, "Reality in the Economic Analysis of Tort Law: Does Tort Law Really Deter?," UCLA Law Review, 42 (1994): 377-444, at 443.

10. Danzon, supra note 4 , at 222.

11. Id.

12. Id.; Weiler et al., supra note 4 , at 112.

13. D. Shuman, "The Psychology of Deterrence in Tort Law," Kansas Law Review, 42 (1993): 115-68, at 121.

14. See Landes and Posner, supra note 5, at 57-58; Shavell, supra note 9, at 8; Keeton et al., supra note 9, at 25-26; Schwartz, supra note 9 , at 443 .

15. Patricia Danzon, a perceptive critic of the current system, argues that "the malpractice system departs significantly from [the] theoretical ideal [of general deterrence], but the most extreme criticisms are unfounded. Danzon, supra note 4, at 222. She further argues that the deterrence value of the system justifies its high cost, even taking into account its many flaws, although she strenuously argues for numerous modifications to the current structure of malpractice law. Id. at 226-27.

16. See Shuman, supra note 13 , at 152-53.

17. See Weiler et al., supra note 4 , at 112.

18. See Danzon, supra note 4, at 29 (filed claims represent small percentage of negligent injuries); Weiler, supra note 2 , at 12-13 (same).

19. See IOM Report, supra note 1, at 36-37 (fear of malpractice liability results in nondisclosure of errors to patients); Weiler et al., supra note 4, at 139-40 (patients resort to initiating litigation in order to obtain information about medical errors); W.M. Sage, K.E. Hastings, and R.A. Berenson, "Enterprise Liability for Medical Malpractice and Health Care Quality Improvement," American Journal of Law $\mathcal{O}$ Medicine, 20 (1994): 1-28, at 4 ("many physicians and other health care providers are unlikely to admit their negligent behavior to themselves, much less to their patients").

20. See Danzon supra note 4, at 197-98; Shuman, supra note 13 , at 120 .

21. See Shuman, supra note 13 , at 123 (arguing that tort decisions reflect uncertainty over the rule of law). But see Danzon, supra note 4, at 42. Danzon undertook an empirical examination of a large number of litigated malpractice cases in order to examine, among other things, the charge that "decisions by juries and judges typically do not follow the precepts of the law"; "the conclusion of this analysis, based on almost 6,000 claims resolved nationwide in two different time periods, is that the courts are far from arbitrary and the law makes a substantial difference." Id.

22. See Danzon, supra note 4, at 42 ("More than 90 percent of claims are settled out of court.").

23. See Weiler et al., supra note 4, at 131; Danzon, supra note 4, at 226. See also R. Posner, Economic Analysis of the Law, 5th ed. (New York: Aspen Law \& Business, 1998): at 222-24 (tort law in general, and medical malpractice law specifically, deters harmful conduct); Schwartz, supra note 9, at 443 (tort law 
provides "something significant" in terms of deterrence).

24. See generally G. Calabresi, The Cost of Accidents (New Haven: Yale University, 1970); G. Priest, "The Invention of Enterprise Liability: A Critical History of the Intellectual Foundations of Modern Tort Law," Journal of Legal Studies, 14 (1985): 461; R. Rabin, "Some Thoughts on the Ideology of Enterprise Liability," Maryland Law Review, 55 (1996) 1190-209.

25. See McDonald v. Hampton Training School for Nurses, 486 S.E.2d 299 (Va. 1997); Gilbert v. Sycamore Municipal Hospital, 622 N.E.2d 788 (Ill. 1993); Kashishian v. Port, 481 N.W.2d 277 (Wis. 1992). See also K. Abraham and P. Weiler, "Enterprise Medical Liability and the Evolution of the American Health Care System," Harvard Law Review, 108 (1994), 381-436, at 386-89.

26. See Darling v. Charleston Community Memorial Hospital, 211 N.E.2d 253 (Ill. 1965), cert. denied, 383 U.S. 946 (1966). See generally Abraham and Weiler, supra note 25, at 388-90.

27. See Thompson v. Nason Hospital, 591 A.2d 703 (Pa. 1991).

28. B. Furrow, "Enterprise Liability and Managed Care Reform: Managing Care and Managing Risk," Saint Louis University Law Review, 39 (1994): 77-132, at 110-11.

29. The American Law Institute, Reporters'Study: Enterprise Responsibility for Personal Injury, vol. 2, Approaches to Legal and Institutional Change (Philadelphia: American Law Institute, 1991): at 114 [hereafter cited as ALI Study].

30. Id. at $114-15$.

31. Id. at 114-15. Professor Paul Weiler was the reporter for the ALI study and he, along with Professor Kenneth Abraham, has written extensively and trenchantly on hospital-based enterprise liability. See Weiler, supra note 2; Abraham and Weiler, supra note $25 ; \mathrm{K}$. Abraham and P. Weiler, "Enterprise Liability and the Choice of the Responsible Enterprise," American Journal of Law or Medicine, 20 (1994): 29-39.

32. The ALI study estimated that its recommended form of enterprise liability (in which the hospital becomes the sole defendant only for "physician malpractice that injures patients who are treated within that hospital") would apply to "roughly 90 percent of the incidents now giving rise to malpractice claims and payments." ALI Study, supra note 29, at 114 (footnote omitted). The study used 1984 data, however; the more recent trends move surgery and other major procedures out of hospitals and into outpatient settings. See W. Sage, "Enterprise Liability and the Emerging Managed Health Care System," Law and Contemporary Problems, 60 (1997): 159-210, at 163.

33. See ALI Study, supra note 29, at 119; Abraham and Weiler, supra note 25 , at 406 .

34. See Danzon, supra note 4 , at 225-26; Schwartz, supra note 9 , at 401-02.

35. See E. Becher and M. Chassin, "Improving Quality, Minimizing Error: Making It Happen," Health Affairs, 20, no. 3 (2001): $68-81$, at 71 .

36. See D. Dobbs, The Law of Torts (St. Paul, Minnesota: West, 2000): at 631 (causation of injury an element of a medical malpractice action); Weiler et al., supra note 4, at 112.

37. Danzon, supra note 4 , at 29 ; Weiler, supra note 2 , at $12-13$.

38. See Weiler, supra note 2 , at 14.

39. See Shuman, supra note 13 , at $121-23$

40. See Abraham and Weiler, supra note 25, at 408 ("Malpractice liability insurers, not physicians, actually pay the awards to malpractice claimants - thus diluting the direct incentives that physicians might otherwise have to enhance their quality of care in order to avoid paying jury verdicts to injured patients.").

41. Danzon, supra note 4, at 86-87 ("In principle, ... liability insurance need not interfere with deterrence if insurance premiums adjust to reflect the insured's quality of care. As a theoretical proposition, if the price of insurance coverage accurately reflects the insured's probability of loss - perfect experience rating insurance does not interfere with incentives for care.").

42. See Abraham and Weiler, supra note 25, at 409-10; Danzon, supra note 4 , at 87.

43. See Danzon, supra note 4 , at 87 .

44. Abraham and Weiler, supra note 25, at 408.

45. See Danzon, supra note 4, at 95 ("Although [malpractice insurance] rating structure is extremely rigid, to some extent it reflects the fact that the small pool of policyholders and the instability of loss experience over time preclude drawing finer classifications with actuarial credibility."); Weiler, supra note 2, at 76-79 (discussing barriers to experience rating for physicians' malpractice experience). Abraham and Weiler explain the absence of experience rating in physicians' malpractice insurance in the following terms:

[F]rom the individual physician's perspective, being named as a malpractice defendant is a comparatively rare event. It occurs only a handful of times in the entire careers of even physicians who practice in the high risk specialties. Even the actual commission of malpractice produces a tort claim only if the error in question happened to cause an injury serious enough to make litigation worthwhile.... Thus, with the exception of a tiny number of malpractice recidivists, past claims experience tends not to be a reliable index of future liability risk.

K. Abraham and P. Weiler, supra note 25, at 410 (footnotes omitted).

46. See Weiler, supra note 2 , at 76.

47. See Abraham and Weiler, supra note 25 , at $410-11$.

48. Id. at 411

49. Physicians' non-economic incentives to avoid malpractice claims, such as the time required to respond to claims and the emotional toll exacted by claims of negligence, ought not be overlooked. See Shuman, supra note 13, at 130-31 (" $[1] \mathrm{n}$ the case of malpractice actions against physicians, ... the time demands of defending a claim on the physician's practice, the potential impact of the claim on patient demand, and the emotional distress of an unresolved claim are significant uninsurable costs for physicians.") (foornote omitted). But the malpractice system's attempts to transmit economic signals to minimize error are gravely compromised by the structure of physician liability insurance.

50. See Abraham and Weiler, supra note 25, at 414.

51. Id. Some physicians' malpractice carriers apparently perform this role to some limited degree. Id. Emerging common law theories of corporate negligence and ostensible agency have moved hospitals in the direction of assuming such a role; a shift to enterprise liability would heighten their interest in such oversight. Id.

52. IOM Report, supra note 1 , at 4 ("Preventing errors means designing the health system at all levels to make it safer. Building safety into processes of care is a more effective way to reduce errors than blaming individuals....").

53. Id.

54. ALI Study, supra note 29, at 124.

55. Id. at 123. Compare the following analysis from the IOM report:

The common initial reaction when an error occurs is to find and blame someone. However, even apparently single events or errors are due most often to the convergence of multiple contributing factors. Blam- 
ing an individual does not change those factors and the same error is likely to recur. Preventing errors and improving safety for patients require a systems approach in order to modify the conditions that contribute to errors. People working in health care are among the most educated and dedicated workforce in any industry. The problem is not bad people; the problem is that the system needs to be made safer.

IOM Report, supra note 1 , at 42 . This is not to paper over the glaring difference between the IOM's approach and that advocated by enterprise liability theorists. The IOM repeatedly cautions against the "blame game," arguing that "blaming an individual does little to make the system safer and prevent someone else from committing the same error." Id. at 4 . The IOM does, however, recognize that accountability is appropriate, thereby suggesting at least that compensation is a proper role for a negligence system. Id. ("People must still be vigilant and held responsible for their actions."). The ALI study, due to its focus on modification of the current tort system, approaches the topic of error reduction from the deterrence perspective. See ALI Study, supra note 29, at 123.

56. Id.

57. See Abraham and Weiler, supra note 25, at 416-17.

58. Id. at 416 .

59. Id. at 396-97.

60. Id. at 416-17.

61. See Sage, Hastings, and Berenson, supra note 19, at 2. Sage, Hastings, and Berenson worked with the "medical malpractice working group of the White House Task Force on Health Care Reform," among other capacities, in the health reform effort. Id. at 1. See also Health Security Act, H.R. 3600, 103d Cong., 1st Sess. $\$ 5311$ (1993).

62. See Sage, Hastings, and Berenson, supra note 19, at 1-2 (the authors "agree that accountability in health care must be redefined if true quality is to be achieved," and therefore advocate a shift to enterprise liability).

63. See Health Security Act, supra note $61, \$ 5311$ (a) (authorizing the creation of state-based demonstration projects to test "whether substituting liability for medical malpractice on the part of the health plan in which a physician participates for the personal liability of the physician will result in improvements in the quality of care provided under the plan....").

64. See Sage, Hastings, and Berenson, supra note 19, at 2-5. 65. A. Bernstein et al., "Trend Data on Medical Encounters: Tracking a Moving Target," Health Affairs, 20, no. 2 (2001): 58 72, at 65-66. See also P. Danzon, "Tort Liability: A Minefield for Managed Care?,” Journal of Legal Studies, 26 (1997): 491-519, at 515 .

66. Cal. Bus. \& Prof. Code $\$ 2216.2$ (a) (West $1990 \&$ Supp. 2001 ), added by Stat. 1999 , c. $944, \$ 3$. See also R. Kuelthau, "Ambulatory Surgery Centers - Medical Clinics and the $\mathrm{Na}$ tional Practitioner Data Bank," Marquette Law Review, 79 (1996): $819-31$, at 819 (noting, in the context of mandatory reporting to the National Practitioner Data Bank, the increase in outpatient procedures).

67. Sage, Hastings, and Berenson, supra note 19 , at 11.

68. Furrow, supra note 28, at 125.

69. Id.; C. Havighurst, "Vicarious Liability: Relocating Responsibility for the Quality of Medical Care," American Joumal of Law o Medicine, 26, no. 1 (2000): 7-29, at 8; Sage, Hastings, and Berenson, supra note 19, at 9-10.

70. Sage, Hastings, and Berenson, supra note 19 , at 9.

71. Id. at 11-12.
72. Id. at $13-14$.

73. Id. at 14. See also Furrow, supra note 28, at 99-100 (discussing information systems).

74. The Clinton plan, after all, included plan-based enterprise liability only on a demonstration basis. See Health Security Act, supra note $61, \$ 5311$ (a). See also Sage, Hastings, and Berenson, supra note 19, at 10-13 (arguments for plan-based enterprise liability couched in conditional terms, assuming the adoption of the other broad reforms proposed in the Health Security Act).

75. Havighurst, supra note 69, at 10-14 (describing the tendency of MCOs to distance themselves from the delivery of health care and their failure to undertake efforts to encourage their contracting providers to improve the quality of care).

76. See Sage, Hastings, and Berenson, supra note 19, at 10-15.

77. Id. at 14

78. Id. at 23-24.

79. See J. Gable, "Ten Ways HMOs Have Changed During the 1990s," Health Affairs, 16, no. 3 (1997): 134-145, at 136; W. Sage, "Regulating Through Information Disclosure Laws and American Health Care," Columbia Law Review, 99 (1999): 1701829 , at 1776.

80. See J. Fossett and F. Thompson, "Back-off not Backlash in Medicaid Managed Care," Journal of Health Politics, Policy and Law, 24, no. 5 (1999): 1159-72, at 1167; R. Berenson, "Beyond Competition," Health Affairs, 16, no. 2 (1997): 171-80, at 17273; Danzon, supra note 65, at 515-16.

81. See Sage, supra note 79, at 1776-77.

82. Id. at 1777. See D. Frankford, "Regulating Managed Care: Pulling Tails to Wag the Dogs," Journal of Health Politics, Policy and Law, 24, no. 5 (1999): 1191-200, at 1198 ("Overall, then, now and in the foreseeable future, the dream of getting plans to compete over quality remains just that, a dream. The dominant form of competition among managed care plans is likely to remain price competition....").

83. U.S. Department of Health and Human Services, Office of Inspector General, Managed Care Organization Nonreporting to the National Practitioner Data Bank: A Signal for Broader Concern, OEI-01-99-00690 (Washington, D.C.: Department of Health and Human Services, May 2001).

84. Id. at 4.

85. Id. at 6 .

86. Id. at 6-7.

87. See A. Enthoven, H. Schauffler, and S. McMenamin, "Consumer Choice and the Managed Care Backlash," American Joumal of Law or Medicine, 27 (2001): 1-15, at 3 (as consumers have perceived reductions in choice as providing little benefit, they have insisted on broader choice).

88. J. Hacker and T. Marmor, "How Not To Think About 'Managed Care,'" University of Michigan Journal of Law Reform, 32 (1999): 661-84.

89. Id. at $675-79$.

90. Havighurst, supra note 69, at 10-11 (footnotes omitted). Abraham and Weiler anticipated that plans ("financed-based enterprises"), as opposed to hospitals or other "delivery-based enterprises," would run into such difficulties if relied upon as agents of quality control in enterprise liability:

[F]inancing-based enterprises suffer important disadvantages relative to delivery-based enterprises. One such disadvantage is that financing-based enterprises are one step removed from the actual delivery of care and consequently would find it more difficult to affect the actual quality of care.... The escalation of 
health care costs over the past two decades displays the difficulties that these enterprises have encountered in accomplishing their cost containment objectives.... These enterprises probably would have difficulty controlling costs in their effort to enhance the quality of care under financing-based enterprise liability.

Abraham and Weiler, supra note 25, at 418 (footnotes omitted). 91. See P. Fronstin, "Defined Contribution Health Benefits," EBRI Issue Brief, no. 231 (March 2001): 1-30, at 3; C. Crutcher, "The 'Tipping Point' for Employer-Sponsored Health Insurance?," Health Care Purchaser (April 2001): 1, 3-4, at 1.

92. See S. Heffler et al., "Health Spending Growth Up in 1999; Faster Growth Expected in Future," Health Affairs, 20, no. 2 (2001): 193-203, at 196 ("Insurance premiums grew faster in 1999 (6.5 percent) than in the $1993-1998$ period (5.0 percent annual average growth).... We anticipate continued near-term acceleration in health insurance premiums - 9.3 percent in 2000 and 10.5 percent in 2001.") (footnote omitted).

93. See Fronstin, supra note 91, at 5-6.

94. See J. Jacobi, "Medicaid Expansion, Crowd-Out, and Limits of Incremental Expansion," Saint Louis University Law Journal, 45 (2001): 79-116, at 86.

95. See Fronstin, supra note 93, at 3-4; Crutcher, supra note 91 , at 1.

96. It may be that employees would have a broader range of choice of health plans under some defined-contribution plans. See Fronstin, supra note 93, at 11-12. Employers may well wish to leave plan selection more clearly to employees in order to avoid the risk of new common law or statutory causes of action for negligence in selection of a health plan. Id. at 11 .

97. See Fronstin, supra note 93, at 15-17 ("Under an individual market, or non-group market, employees would be responsible for choosing their own health insurance, and could choose any health plan available in the market."); S. Trude and P. Ginsberg, Are Defined Contributions a New Direction for EmployerSponsored Coverage?, Issue Brief No. 32 (Washington, D.C.: Center for Studying Health System Change, October 2000): at 3 (describing plan by which employers would provide vouchers for employees to purchase coverage on the individual insurance market).

98. See M. Pauly and A. Percy, "Cost and Performance: A Comparison of the Individual and Group Health Insurance Markets," Journal of Health Politics, Policy and Law, 25 (2000): 9-26, at 24 ("individual insurance is expensive for what the buyer gets"); Trude and Ginsberg, supra note 97, at 3 (citing EBRI data in support of claim that "premiums to purchase comparable insurance on the individual market would cost 32 percent more for employees of companies with more than 1,000 workers, and 24 percent more in medium-size companies") (footnote omitted); J. Steinhauer, "Managing Benefits: Let Workers Do It," New York Times, December 3, 2000, Money and Business section ("talk to anyone who has bought an individual health insurance policy in the last decade and he or she will tell you that there aren't many affordable offerings out there").

99. See Pauly and Percy, supra note 98, at 20-21 (describing risk-rating of individual insurance); Trude and Ginsberg, supra note 97 , at 3 (same).

100. See Defined Contributions: The Search for New Visions, Issue Brief No. 37 (Washington, D.C.: Center for Studying Health System Change, April 2001): at 3-4 (describing Internet company HealthSync's version of a consumer choice plan, where even though individual employees control their own plan choices, "the risk pool from the employer is maintained so that 'the young subsidize the old and the healthy subsidize the sick, so that the social contract of insurance is maintained").

101. It could be argued that the shift from a regime in which the employer chooses one or a handful of plans for employees to one in which employees have unfettered access (cost aside) to every licensed plan will improve quality by encouraging competition among plans. In light of the well-understood information deficits standing in the way of an individual consumer's informed choice of a plan, advocates of quality improvement have emphasized the role of an informed sponsor in culling plans and organizing competition. See A. Enthoven, "The History and Principles of Managed Competition," Health Affairs (Supp. 1993): 24-48, at 30-32 (describing the role of the sponsor in managed competition model). Without any sponsor to monitor or assist in consumer choice, and with plans clearly competing on the basis of price rather than quality (see Havighurst, supra note 69 , at $13)$, the gains to be expected in quality would be slim to none. The steep price differential between group and individual health insurance is probably sufficiently high to discourage mass movement in this direction, however, and talk of the effects of employee choice on quality is therefore probably academic.

102. One firm offering Internet-based, patient-directed plans is Lumenos, which bills itself as "the antidote to managed care." See < http://www.lumenos.com/corporate_info/overview> (last visited October 29, 2001).

103. J. Goldsmith, "The Internet and Managed Care: A New Wave of Innovation," Health Affairs, 19, no. 6 (2000): 42-56, at 42.

104. S. O'Dell, M. Franz, and P. Kelly, The Emerging Health Plan: Consumerized and Digitized (Long Beach, California: First Consulting Group, June 2000): at 1, available at <http:// www.doghouse.com/pdfs/Emerging.pdf $>$ (emphasis in original).

105. See S. Parente, "Beyond the Hype: A Taxonomy of EHealth Business Models," Health Affairs, 19, no. 6 (2000): 89-102; D. Bates and A. Gawande, "The Impact of the Internet on Quality Measurement," Health Affairs, 19, no. 6 (2000): 104-14.

106. See Lumenos, supra note 102; HealthMarket, Inc., "Self Directed Health Plans," at < https:/www.healthmarket.com/M/ consumers/5027.shtml > (last visited October 29, 2001); Vivius, Inc., "A Personalized Healthcare System," at <http:// www.vivius.com > (last visited October 29, 2001); Definity Health, Inc., "Consumer Control," at <http://www.definityhealth.com/ marketing/advantage.html > (last visited October 29, 2001); MyHealthBank, "Services," at <http://www.myhealthbank.com/ corp/homepage/services.jsp > (last visited October 29, 2001).

107. See Crutcher, supra note 91 , at 3.

108. Id.

109. Goldsmith, supra note 103 , at 50, quoting J.P. Lathrop and D. Carlebach, "HMOs'R'us: A Prescription for the Future," Strategy + Business (Fourth Quarter 1998): 16-20.

110. Medical savings accounts, or MSAs, were created as a demonstration project in 1996 as part of the Health Insurance Portability and Accountability Act, Pub. L. No. 104-191. MSAs permit mid-sized employers to offer a tax-sheltered benefit to employees in the form of funds deposited in a savings account, for use in paying for health care. The employees are required to pay a deductible, and are protected from large expenses by catastrophic insurance coverage after they reach a high attachment point. The funds in their medical savings account, if unspent in the year deposited, roll over from year to year, and may be used by the employee in future years for medical expenses or retirement savings. See generally R. Jefferson, "Medical Savings Accounts: Windfalls for the Healthy, Wealthy \& Wise," Catholic University Law Review, 48 (1999): 685-726. The number of MSA enrollees is capped at 750,000 . Set by the terms of the statute to 
expire in 2000, the MSA experiment was extended two years, to 2002, and MSAs were renamed "Archer MSAs." Legislation has been introduced to make MSAs permanently available to all, a measure that has the support of the Bush administration. See H.R. 1524, 107th Congress, 1st Sess. Disintermediated plans are also akin to flexible spending accounts (FSAs), through which employees may dedicate pre-tax income to payment of medical expenses not covered by health insurance. The accounts are typically administered by a financial agent. Any funds not used in the course of a year are forfeited. See Internal Revenue Code $\$ 105(\mathrm{~b})$.

111. Crutcher, supra note 91 , at 1 . (footnotes omitted).

112. See websites identified in notes 102 and 106.

113. Id.

114. Id.

115. Definity Health, Inc., supra note 106.

116. Lumenos, Inc., supra note 102.

117. HealthMarket, Inc., supra note 106.

118. Vivius, Inc., has a slightly different model. Although members of Vivius may, as with the other disintermediated plans, choose their own provider and health care, they do not pay on a fee-for-service basis. As one commentator explains:

Vivius functions like an auction site, bringing providers and patients together based on competitively bid capitation rates. There is no claims management; providers set their own capitated rate for individual subscribers, adjusted for age and sex. Patients can compare the aggregated cost of the network they select with the employer-provided contribution to determine how much they will pay out of pocket each month and the annual maximum family contribution. Their medical care above this maximum amount will be insured by a wraparound indemnity insurance product.... Vivius's principal role is that of market maker. The health plan role is eliminated, and the only "insurance" in the model is the catastrophic-cost "umbrella" purchased by subscribers and an outof-network coverage premium paid by providers.

Goldsmith, supra note 103, at 50. See Vivius, Inc., supra note 106. 119. Fronstin, supra note 93 , at 6 .

120. Id.

121. See generally Jefferson, supra note 110; G. Scandlen, "Reply: MSAs Can Be a Windfall for the Rest of Us Too," Catholic University Law Review, 49 (2000): 679-95. See also K. Thorpe, "Managed Care as Victim or Villain?," Journal of Health Politics, Policy and Law, 24 (1999) 949-56, at 954 (describing the costs and benefits of medical savings accounts).

122. See, e.g., P.A. Gomez, "Promises and Pitfalls: An Analysis of the Shifting Constitutional Interests Involved in the Context of Demanding a Right to Treatment in Health Care," Albany Law Review, 64 (2000): 361-396, at 385-86.

123. See "Investment Banker Predicts New Era of "Virtual Hospitals," California Health Law Monitor, 6, no. 8 (April 20, 1998) (even in 1998, there were predictions that HMOs would be "disintermediated" and bypassed by networks being formed around hospitals and physicians).

124. See Havighurst, supra note 69.

125. See Studdert and Brennan, supra note 8.

126. See Becher and Chassin, supra note 35 , at 68-71; IOM Report, supra note 1, at 3. See also J. Reason, "Human Error: Models and Management," British Medical Jourmal, 320 (2000): 768-70; L. Leape et al., "Promoting Patient Safety by Preventing Medical Error," JAMA, 280 (1998): 1444-47; J. Reason, Human Error (Cambridge, England: Cambridge University, 1990).
127. Becher and Chassin, supra note 35 , at 69.

128. Id. at 71 .

129. Abraham and Weiler, supra note 25 , at 418.

130. See Danzon, supra note 4 , at 95 ; Weiler, supra note 2 , at 76-79.

131. IOM Report, supra note 1 , at 4 . See Leape et al., supra note 126 , at 1445 .

132. Reason, "Human Error: Models and Management," supra note 126 , at 768 .

133. See IOM Report, supra note 1 , at 31 .

134. Id. at 34. See E. Bradley et al., "A Qualitative Study of Increasing b-Blocker Use After Myocardial Infarction," JAMA, 285 (2001): 2604-11. Similarly, anesthesia errors often can be traced to a slip or lapse by a human, but systemic review can "prescribe new procedures and technologies" capable of screening for human error. See Abraham and Weiler, supra note 25, at 411-12; R. Raschke et al." "A Computer Alert System to Prevent Injury from Adverse Drug Events," JAMA, 280 (1998): 1317-20 (drug errors).

135. IOM Report, supra note 1 , at 51 .

136. Studdert and Brennan, supra note 8, at 217.

137. IOM Report, supra note 1 , at 4.

138. Id. at 18 .

139. Id. at $95-96$.

140. Sage, Hastings, and Berenson, supra note 19 , at 13.

141. Id. at 14.

142. Abraham and Weiler, supra note 25 , at 410-11.

143. Rabin, supra note 24, at 1198; A. Sykes, "The Economics of Vicarious Liability," Yale Law Joumal, 93 (1984): 1231-80, at 1261.

144. See ALI Study, supra note 29, at 124; Sage, supra note 32, at $164-65$.

145. IOM Report, supra note 1 , at 3.

146. Bradley et al., supra note 134, at 2609.

147. See Danzon, supra note 65, at 515-16; Abraham and Weiler, supra note 31 , at 33-34.

148. See W. Sage, "Principles, Pragmatism, and Medical Injury," IAMA, 286 (2001): 226-28, 227.

149. Havighurst, supra note 69 , at 10.

150. Dobbs, supra note 36, at 977-81.

151. See Tarasoff $v$. Regents of the University of California, 551

P.2d 334 (Cal. 1976); Rabin, supra note 24, at 1199-200.

152. See Davis $v$. Nevada National Bank, 737 P.2d 503 (Nev. 1987); Connor v. Great Western Savings \& Loan Association, 447 P.2d 609 (Cal. 1968).

153. See Sykes, supra note 143, at 1273-75.

154. IOM Report, supra note 1 , at 60.

155. The Clinton administration added funding and reorganized a center in the Agency for Healthcare Research and Quality, naming it the Center for Quality Improvement and Patient Safety. See "Clinton-Gore Administration Announces New Actions to Improve Patient Safety and Assure Health Care Quality" (February 19, 2000), at <http://www.ahcpr.gov/wh21900.htm>. The Bush administration created an interagency Patient Safety Task Force, avowedly for the purpose of pursuing the IOM's errorreduction agenda and specifically to pursue the IOM's goal of "reducing the number of medial errors by 50 percent over 5 years." See Agency for Healthcare Research and Quality, "Patient Safety Task Force: Fact Sheet" (April 2001), at < http:// www.ahcpr.gov/qual/taskforce/psfactst.htm >.

156. IOM Report, supra note 1 , at 157-70. See Bradley et al., supra note 134; L. Leape et al., "Systems Analysis of Adverse Drug Events," JAMA, 274 (1995): 35-43; R. Raschke et al., supra note 134; Abraham and Weiler, supra note 25 , at 411-14.

157. See E. Becher and M. Chassin, "Improving the Quality of 
Health Care: Who Will Lead?," Health Affairs, 20, no. 5 (2001): 164-79.

158. IOM Report, supra note 1 , at 67.

159. For example, punitive damages would seem unavailable if the managed care organization took reasonable steps to encourage safety. This assumes, of course, that the enterprise liability system would include a punitive damages feature.

160. See e.g., OIG Compliance Program for Individual and Small Group Physician Practices, 65 Fed. Reg. 59,434 (October 5, 2000); OIG Compliance Program for Nursing Facilities, 65
Fed. Reg. 14,289 (March 16, 2000); OIG Compliance Program for Hospices, 64 Fed. Reg. 54,031 (October 5, 1999); OIG Compliance Program Guidance for Hospitals, 63 Fed. Reg. 8,987 (February 23, 1998).

161. E. McGlynn and R. Brook, "Keeping Quality on the Policy Agenda," Health Affairs, 20, no. 3 (2001): 82-90, at 82.

162. Committee on Quality of Health Care in America, Institute of Medicine, Crossing the Quality Chasm: A New Health System for the 21st Century (Washington, D.C.: National Academy Press, 2001): at iii. 